\title{
ANALISIS RISIKO KESEHATAN LINGKUNGAN (ARKL) PARAMETER AIR MINUM UNTUK PEKERJA DI KABUPATEN PASURUAN TAHUN 2017
}

\author{
Linda Agustina \\ Departemen Kesehatan Lingkungan, Fakultas Kesehatan Masyarakat \\ Universitas Airlangga Surabaya \\ Email: agustinalinda67@gmail.com
}

\begin{abstract}
Water is a basic necessity for life that most importance substance. Water must be available sufficiently in quality, quantity and continuity for human survival. Ideal drinking water should be clean, colorless, non-sticky and odorless. Drinking water should not contain pathogenic germs and all living things that endanger human health, do not contain chemicals that can change bodily functions and can be economically harmful. The purpose of this study is to analyze environmental health risks in drinking water parameters for workers in Pasuruan Regency in 2017. The method of this research is by collecting secondary data, which is 32 points of location of drinking water in Pasuruan Regency. Secondary data were obtained from the results of laboratory tests, and data on the various parameters of BBTKLPP laboratory examination along with SNI and related regulations and literature from several sources to support the available data. Then the secondary data obtained is calculated the maximum and minimum of concentration values, intake and health risk characteristics of each chemical agent in the parameters of drinking water. The research results show that the concentration of $\mathrm{Fe}$ in drinking water exceeds the predetermined quality standard, namely Cmax 0.8364.
\end{abstract}

Keywords: Drinking Water, Environmental Health Risk Analysis, Work.

\begin{abstract}
ABSTRAK
Air merupakan kebutuhan dasar bagi kehidupan yang sangat penting. Air harus tersedia cukup secara kualitas, kuantitas dan kontinuitas untuk kelangsungan hidup manusia. Air minum yang ideal seharusnya bersih, tidak berwarna, tidak bersa dan tidak berbau. Air minum seharusnya tidak mengandung kuman pathogen dan segala makhluk hidup yang membahayakan kesehatan manusia, tidak mengandung zat kimia yang dapat mengubah fungsi tubuh dan dapat merugikan secara ekonomis. Tujuan dari penelitian ini untuk menganalisis risiko kesehatan lingkungan pada parameter air minum untuk pekerja di Kabupaten Pasuruan pada tahun 2017. Metode penelitian ini adalah dengan pengumpulan data sekunder yaitu sebanyak 32 titik lokasi air minum di Kabupaten Pasuruan. Data sekunder didapatkan dari hasil pemeriksaan laboratorium, dan data macam-macam parameter pemeriksaan laboratorium BBTKLPP berserta SNI dan peraturan terkait serta literatur dari beberapa sumber untuk mendukung data yang tersedia. Lalu data sekunder yang diperoleh dihitung nilai konsentrasi, jumlah asupan serta karakteristik risiko kesehatan maksimal dan minimal tiap agen kimia pada parameter air minum. Hasil penelitan menunjukkan konsentrasi dari Fe dalam air minum melebihi baku mutu yang telah ditetapkan yaitu Cmax 0.8364.
\end{abstract}

Kata kunci : Air Minum, Analisis Resiko Kesehatan Lingkungan, Pekerja. 


\section{PENDAHULUAN}

Kesehatan Lingkungan merupakan suatu keseimbangan ekologi yang harus ada antara manusia dan lingkungan agar menjamin keadaan manusia sehat. Upaya Kesehatan Lingkungan merupakan ditujukan untuk mewujudkan kualitas lingkungan yang sehat, baik fisik, kimia, biologi maupun social yang memungkinkan setiap orang mencapai derajat kesehatan yang setinggi tingginya. Peraturan Menteri Kesehatan RI Nomor 173/MENKES/VII/1977 pencemaran air adalah suatu peristiwa masuknya zat ke dalam air yang mengakibatkan kualitas (mutu) air tersebut menurun sehingga dapat mengganggu atau membahayakan kesehatan masyarakat. ${ }^{1}$ Peraturan Pemerintah RI Nomor 20 Tahun 1990 pencemaran air adalah masuknya atau dimasukkannya makhluk hidup, zat, energi, atau komponen lain kedalam air oleh kegiatan manusia, sehingga kualitas air turun sampai ke tingkat tertentu yang membahayakan, yang mengakibatkan air tidak berfungsi lagi sesuai peruntukkannya. $^{2}$

Air merupakan kebutuhan dasar bagi kehidupan, manusia selama hidupnya juga memerlukan air. ${ }^{3}$ Air minum adalah salah satu kebutuhan utama manusia, bagi kehidupan makhluk hidup di bumi merupakan zat terpenting. Air harus tersedia cukup secara kualitas, kuantitas dan kontinuitas untuk kelangsungan hidup manusia. Senyawa lain tidak dapat menggantikan fungsi air bagi kehi - dupan.

Air minum yang ideal seharusnya bersih, tidak berwarna, tidak bersa dan tidak berbau. Air minum seharusnya tidak mengandung kuman pathogen dan segala makhluk hidup yang membahayakan kesehatan manusia, tidak mengandung zat kimia yang dapat mengubah fungsi tubuh dan dapat merugikan secara ekonomis. Air itu seharusnya tidak korosif, tidak meninggalkan endapan pada seluruh jaringan distribusinya. Atas dasar tersebut dibuat standart air minum yaitu suatu peraturan yang memberi petunjuk tentang konsentrasi berbagai parameter yang sebaiknya diperbolehkan ada didalam air minum tidak melebihi baku mutu. ${ }^{3}$

Peraturan Menteri Kesehatan Nomor 492/Menkes/Per/IV/2010 tentang Persyaratan Kualitas Air Minum, terdapat 18 parameter wajib kimiawi yang diperiksa kandungannya dan dapat mempengaruhi kualitas air minum. ${ }^{4}$ Namun untuk menganalisis dengan metode ARKL (Analisis Risiko Kesehatan Lingkungan), parameter tersebut harus memiliki nilai Reference Dose (RfD). Beberapa parameter wajib kimiawi yang memiliki nilai RfD diantaranya adalah Besi (Fe). Mangan $(\mathrm{Mn})$, Seng ( $\mathrm{Zn})$, Nitrit $\left(\mathrm{NO}_{2}{ }^{-}\right)$, Nitrat $\left(\mathrm{NO}_{3}{ }^{-}\right)$. Pada parameter tersebut apabila terjadi peningkatan konsentrasi yang melebihi baku mutu maka akan dapat mengganggu atau membahayakan kesehatan masyarakat. ${ }^{5}$ 


\section{Lokasi Kabupaten Pasuruan menurut} kondisi eksisting, peningkatan jumlah penduduk dan perubahan tata guna yang terjadi akan berimbas pada peningkatan akan kebutuhan air dan berkurangnya wilayah konservasi air sehingga mengakibatkan pengurangan ketersediaan air baik dari segi kuantitas maupun kualitasnya. Ketersediaan air tanah merupakan salah satu faktor pendukung dan penentu bagi pengembangan suatu wilayah. Pada beberapa tahun terakhir ini Kabupaten Pasuruan dan sekitarnya telah mengalami kemajuan pem-bangunan yang meningkat pesat, terutama pada sektor industri, pariwisata, perdagangan dan pertanian.

Kondisi kebutuhan air yang tinggi, dengan potensi sumber daya air permukaan dan air tanah, di Kabupaten Pasuruan mengalami pembangunan yang meningkat pesat, salah satunya pada sektor industri. Sektor industri dengan banyak pekerja membutuhkan asupan air minum dengan kuantitas dan kualitas yang cukup. Oleh sebab itu diperlukan Analisis Risiko Kesehatan Lingkungan dengan melihat nilai konsentrasi minimal dan maksimal setiap parameter zat kimia pada air minum. Hal ini dilakukan guna mengetahui potensi faktor risiko atau dampak kesehatan yang ditimbulkan pada tubuh pekerja dari konsentrasi zat kimia pada air minum dari nilai konsentrasi minimal hingga konsentrasi maksimal. Melihat nilai konsentrasi minimal dan maksimal pada setiap zat kimia, hal ini dikarenakan nilai minimal dan nilai maksimal adalah range untuk memperkirakan dampak yang terjadi dari nilai konsentrasi minimal hingga maksimal pada setiap parameter zat kimia dalam air minum. Hal ini perlu dilakukan untuk dapat mengetahui kualitas air di Kabupaten Pasuruan agar dapat mengupayakan manajemen risiko guna pengendalian dampak, pemantauan, dan pengelolaan kesehatan lingkungan.

\section{METODE PENELITIAN}

Penelitian ini dilakukan dengan metode mengumpulkan data sekunder sebanyak 32 titik lokasi air minum untuk pekerja di Kabupaten Pasuruan. Pengumpulan data sekunder ini didapatkan dari profil BBTKLPP Surabaya secara umum, hasil pemeriksaan laboratorium, dan data macam-macam parameter pemeriksaan laboratorium BBTKLPP berserta SNI dan peraturan terkait serta literatur dari beberapa sumber untuk mendukung data yang tersedia. Data sekunder yang telah didapatkan akan dilakukan perhitungan meliputi nilai konsentrasi, jumlah asupan dan karakteristik risiko kesehatan maksimal dan minimal. Selain itu diberikan pengarahan, pembekalan dan materi untuk pengambilan data sekunder.

\section{HASIL DAN PEMBAHASAN}

\section{Hasil}

\section{Identifikasi bahaya}

Tahap identifikasi bahaya merupakan identifikasi terhadap jenis dan sifat serta 
kemampuan yang melekat pada suatu agen risiko yang dapat menyebabkan dampak buruk organisme, sistem, atau sub/populasi. ${ }^{6}$ Berdasarkan hasil uji laboratorium kimia air pada sampel air minum di Kabupaten Pasuruan yang diambil di beberapa lokasi dengan jumlah 32 titik pengambilan pada tahun 2017 menunjukkan 5 zat kimia yang dinilai dapat menimbulkan risiko kesehatan apabila dikonsumsi dalam jangka waktu tertentu. Agen kimia tersebut adalah:

1. Besi (Fe): Didalam air minum, besi menimbulkan warna (kuning), rasa, terjadi kerak pada dinding pipa dan air menjadi keruh. Besi diperlukan tubuh, tetapi apabila dalam dosis besar maka dapat merusak dinding usus dan sampai terjadi kematian. ${ }^{7}$

2. Mangan (Mn): Dalam air, sebagian besar mangan cenderung berikatan dengan partikel dan menetap pada sedimen. Mangan dalam jumlah tertentu dapat masuk kedalam darah dan dapat menembus otak. ${ }^{8}$

3. Seng ( $\mathrm{Zn})$ : Didalam air akan menimbulkan rasa kesat dan dapat meninmbulkan gejala muntaber. Senyawa ini apabila dimasak akan menimbulkan endapan seperti pasir. ${ }^{7}$

4. Nitrat $\left(\mathrm{NO}_{3}\right)$ dan Nitrit $\left(\mathrm{NO}_{2}\right)$ : Nitrit dapat mudah dioksidasikan menjadi nitrat, maka nitrat adalah senyawa yang paling sering ditemukan di dalam air bawah tanah maupun air yang terdapat dipermukaan. Kedua zat tersebut merupakan nutrisi utama bagi pertumbuhan tanaman dan alga. ${ }^{9}$
Tabel 1. Hasil Perhitungan Konsentrasi Parameter Air Minum di Kabupaten Pasuruan

\begin{tabular}{lccccc}
\hline & \multicolumn{5}{c}{ Parameter } \\
\cline { 2 - 6 } & $\mathrm{Fe}$ & $\mathrm{Mn}$ & $\mathrm{Zn}$ & $\mathrm{NO}_{2}{ }^{-}$ & $\mathrm{NO}_{3}{ }^{-}$ \\
\cline { 2 - 6 } & $\mathrm{mg} / \mathrm{L}$ & $\mathrm{mg} / \mathrm{L}$ & $\mathrm{mg} / \mathrm{L}$ & $\mathrm{mg} / \mathrm{L}$ & $\mathrm{mg} / \mathrm{L}$ \\
\hline Baku & 0,3 & 0,4 & 3 & 3 & 50 \\
\hline Cutu & 0.0037 & 0.0127 & 0.0075 & 0.0021 & 0.037 \\
C MAX & 0.8364 & 0.113 & 0.1298 & 0.0627 & 9.6333 \\
\hline
\end{tabular}

Berdasarkan tabel diatas dapat diketahui bahwa $\mathrm{C}$ max dari Besi ( $\mathrm{Fe}$ ) adalah yang paling besar dibandingkan agen kimia lain yang ada didalam parameter air minum untuk pekerja di Kabupaten Pasuruan Tahun 2017 yaitu 0.8364.

\section{Anaslisis dosis respon}

Setelah melakukan identifikasi bahaya selanjutnya melakukan analisis dosis respon yaitu mencari nilai RfD, dan/atau SF dari agen risiko yang menjadi kajian ARKL, serta memahami efek apa saja yang mungkin ditimbulkan oleh agen risiko tersebut pada tubuh manusia.

Pada kajian ARKL air minum di Kabupaten Pasuruan diketahui bahwa agen kimia Nitrat $\left(\mathrm{NO}_{3}\right)$, Nitrit $\left(\mathrm{NO}_{2}\right)$, Seng $(\mathrm{Zn})$, Mangan (Mn) dan Besi (Fe) dapat masuk ke dalam tubuh manusia melalui jalur ingesti dan bersifat non karsinogenik.

Tabel 2. Dosis Respon Agen Kimia Berisiko

\begin{tabular}{ccl}
\hline $\begin{array}{c}\text { Agen } \\
\text { Kimia }\end{array}$ & $\begin{array}{c}\text { Dosis } \\
\text { Respon } \\
\text { (RfD) }\end{array}$ & Efek Kritis dan Referensi \\
\hline & & $\begin{array}{l}\text { Menyebabkan gangguan } \\
\text { penyerapan oksigen dalam }\end{array}$ \\
Besi (Fe) & $0,3 \mathrm{mg} / \mathrm{kg} /$ & $\begin{array}{l}\text { darah, ditandai gejala } \\
\text { pusing, mual. Jika } \\
\text { dikonsumsi dalam jumlah } \\
\end{array}$ \\
& Hari & tinggi dapat merusak saraf. \\
\hline
\end{tabular}




\begin{tabular}{|c|c|c|}
\hline $\begin{array}{l}\text { Agen } \\
\text { Kimia }\end{array}$ & $\begin{array}{l}\text { Dosis } \\
\text { Respon } \\
\text { (RfD) }\end{array}$ & Efek Kritis dan Referensi \\
\hline $\begin{array}{c}\text { Mangan } \\
\text { (Mn) }\end{array}$ & $\begin{array}{l}1,4 \mathrm{E}-1 \\
\mathrm{mg} / \mathrm{kg} / \\
\text { Hari }\end{array}$ & $\begin{array}{l}\text { Hipokolesterolemia,epilepsi, } \\
\text { kekurangan pankreas } \\
\text { ekskrin, siklerosis berganda, } \\
\text { katarak, osteoporosis, } \\
\text { fenilketonuria \& penyakit } \\
\text { kencing maple syrup } \\
\text { (inborn) pada ingesti kronik } \\
\text { pada manusia (NRC, 1989, } \\
\text { Freeland Graves et al., } \\
\text { 1987;WHO, 1973) }\end{array}$ \\
\hline $\begin{array}{l}\text { Seng } \\
(\mathrm{Zn})\end{array}$ & $\begin{array}{c}0,3 \mathrm{mg} / \mathrm{kg} / \\
\text { Hari }\end{array}$ & $\begin{array}{l}\begin{array}{l}\text { Penurunan } \\
\text { aktifitas }\end{array} \\
\text { Zismuthrocyte } \mathrm{Cu} \text {, } \\
\text { sukeroxide } \\
\text { perempuan (ESOD) pada } \\
\text { 1989; Fischer et al., 1984; } \\
\text { Davis et al) }\end{array}$ \\
\hline $\begin{array}{l}\text { Nitrit } \\
\left(\mathrm{NO}_{2}\right)\end{array}$ & $\begin{array}{l}1 \mathrm{E}-1 \\
\mathrm{mg} / \mathrm{kg} / \\
\text { Hari }\end{array}$ & $\begin{array}{l}\text { Methemoglobinemia pada } \\
\text { bayi yang terpajan kronik air } \\
\text { minum (Walton 1951) }\end{array}$ \\
\hline $\begin{array}{l}\text { Nitrat } \\
\left(\mathrm{NO}_{3}\right)\end{array}$ & $\begin{array}{l}1,6 \mathrm{E}+0 \\
\mathrm{mg} / \mathrm{kg} / \\
\text { hari }\end{array}$ & $\begin{array}{l}\text { Gejala klinis dini dari } \\
\text { methemoglobinemia (Bosch } \\
\text { et al, 1977) }\end{array}$ \\
\hline
\end{tabular}

\section{Anaslisis pajanan}

Tabel 3. Hasil Perhitungan Intake Parameter Air Minum di Kabupaten Pasuruan

\begin{tabular}{rrrrrr}
\hline & \multicolumn{5}{c}{ Parameter } \\
\cline { 2 - 6 } & \multicolumn{1}{c}{$\mathrm{Fe}$} & \multicolumn{1}{c}{$\mathrm{Mn}$} & \multicolumn{1}{c}{$\mathrm{Zn}$} & \multicolumn{1}{c}{$\mathrm{NO}_{2}{ }^{-}$} & \multicolumn{1}{c}{$\mathrm{NO}_{3}{ }^{-}$} \\
\cline { 2 - 6 } $\mathrm{mg} / \mathrm{L}$ & \multicolumn{1}{c}{$\mathrm{mg} / \mathrm{L}$} & $\mathrm{mg} / \mathrm{L}$ & \multicolumn{1}{c}{$\mathrm{mg} / \mathrm{L}$} \\
\hline INK & 4.6077 & 0.000 & 9.339 & 2.615 & 0.000 \\
MIN & $2 \mathrm{E}-05$ & 158157 & $98 \mathrm{E}-05$ & $19 \mathrm{E}-05$ & 460772 \\
INK & 0.010 & 0.001 & 0.001 & 0.000 & 0.119 \\
MAX & 41594 & 407223 & 616438 & 780822 & 966376 \\
\hline
\end{tabular}

Berdasarkan tabel diatas dapat diketahui nilai intake minimal dan maksimal dari tiap agen kimia dalam parameter air minum untuk pekerja di Kabupaten Pasuruan Tahun 2017.

\section{Karakteristik risiko}

Tabel 4. Hasil Perhitungan RQ Parameter Air Minum di Kabupaten Pasuruan

\begin{tabular}{cccccc}
\hline & \multicolumn{5}{c}{ Parameter } \\
\cline { 2 - 6 } & $\mathrm{Fe}$ & $\mathrm{Mn}$ & $\mathrm{Zn}$ & $\mathrm{NO}_{2}{ }^{-}$ & $\mathrm{NO}_{3}{ }^{-}$ \\
\cline { 2 - 6 } RQ MIN & 0.000 & 0.001 & 0.000 & 0.000 & 0.000
\end{tabular}

\begin{tabular}{rrrrrr}
\hline & \multicolumn{5}{c}{ Parameter } \\
\cline { 2 - 6 } & \multicolumn{1}{c}{$\mathrm{Fe}$} & \multicolumn{1}{c}{$\mathrm{Mn}$} & $\mathrm{Zn}$ & \multicolumn{1}{c}{$\mathrm{NO}_{2}{ }^{-}$} & \multicolumn{1}{c}{$\mathrm{NO}_{3}{ }^{-}$} \\
\cline { 2 - 6 } $\mathrm{mg} / \mathrm{L}$ & 153591 & 129692 & 311333 & 261519 & \multicolumn{1}{c}{287983} \\
RQ & 0.034 & 0.010 & 0.005 & 0.002 & 0.074 \\
MAX & 719801 & 051592 & 388128 & 60274 & 978985 \\
\hline
\end{tabular}

Berdasarkan tabel diatas dapat diketahui nilai intake minimal dan maksimal dari tiap agen kimia dalam parameter air minum untuk pekerja di Kabupaten Pasuruan Tahun 2017.

\section{Manajemen risiko}

Pada tahap Manajemen Risiko, kasus air minum di Kabupaten Pasuruan berdasarkan hasil perhitungan karakteristik risiko semua agen kimia yang berisiko yaitu Besi (Fe), Mangan (Mn), Seng ( $\mathrm{Zn})$, Nitrit $\left(\mathrm{NO}_{2}\right)$, dan Nitrat $\left(\mathrm{NO}_{3}\right)$. menunjukkan nilai $\mathrm{RQ}<1$. Pengelolaan risiko dilakukan apabila hasil karakteristik risiko menunjukkan hasil yang tidak aman atau nilai RQ $>1$.

\section{Komunikasi risiko}

Berdasarkan hasil perhitungan Analisis Risiko Kesehatan Lingkungan (ARKL) yang telah dilakukan dari tahapannya sebelumnya, diketahui besar risiko yang dihasilkan bahwa besar nilainya dibawah standar yang ditentukan.

\section{Pembahasan}

\section{Identifikasi bahaya}

Berdasarkan Tabel 1 dapat diketahui bahwa $\mathrm{C}$ max dari Besi (Fe) adalah yang paling besar dibandingkan agen kimia lain yang ada didalam parameter air minum untuk pekerja di Kabupaten Pasuruan Tahun 2017 yaitu 0.8364. 
Peraturan Menteri Kesehatan RI No. 492/ MENKES/PER/IV/2010 tentang Persyaratan Kualitas Air Minum, baku mutu kandungan Fe dalam air minum yaitu sebesar $0,3 \mathrm{mg} / \mathrm{L} .{ }^{4}$ Sedangkan dapat diketahu $\mathrm{C}$ max dari Fe dalam air minum untuk pekerja melebihi baku mutu yang telah ditetapkan. Sehingga diperlukan pengendalian kandungan Fe pada air minum dikarenakan sudah melebihi baku mutu. Pengendalian kadar $\mathrm{Fe}$ yang melebihi baku mutu tersebut adalah dengan cara diturunkan konsentrasinya agar sesuai dengan peraturan yang telah ditetapkan sehingga tidak menimbulkan gangguan kesehatan pada pekerja yang mengonsumsi air minum tersebut. Ada beberapa cara menurukan kandungan Fe pada air minum, salah satunya adalah dengan metode filtrasi. Filtrasi adalah proses pengolahan dengan cara mengalirkan air melalui media filtrasi yang disusun dari bahan-bahan butiran dengan diameter dan tebal tertentu. Filtrasi yang dilakukan adalah pada sumber air yang akan digunakan untuk air minum, yang pada dasarnya sumber air di Kabupaten Pasuruan adalah air tanah, sehingga perlu adanya filtrasi pada air tanah Kabupaten Pasuruan. Peningkatan kadar Fe sendiri terjadi karena air tanah sendiri memiliki kandungan $\mathrm{Fe}$ yang tinggi daripada air permukaan.

Besi (Fe) dibutuhkan tubuh dalam pembentukan hemoglobin. Air minum yang mengandung $\mathrm{Fe}$ cenderung menimbulkan rasa mual apabila dikonsumsi. Sekalipun Fe diperlukan tubuh, tetapi dalam dosis yang besar dapat merusak dinding usus, dapat pula menyebabkan kematian akibat rusaknya dinding usus. Kadar Fe yang lebih dari $1 \mathrm{mg} / \mathrm{L}$ akan menyebabkan iritasi mata dan kulit. Apabila kelarutan Besi lebih dari $10 \mathrm{mg} / \mathrm{L}$ akan menyebabkan air seperti bau busuk. Debu Fe juga dapat diakumulasi dalam alveoli dapat menyebabkan berkurangnya fungsi paru-paru. ${ }^{3}$

Kondisi kadar Fe yang tinggi dalam air minum tidak akan baik bagi kesehatan pekerja, hal ini dikarenakan kandungan Fe yang tinggi pada air minum akan menimbulkan masalah kesehatan pada pekerja. Pekerja dengan kondisi kelelahan fisik yang membutuhkan asupan air minum bagi tubuhnya seharusnya mendapatkan air minum dengan kuantitas yang cukup dan kualitas yang memenuhi syarat kesehatan sesuai dengan peraturan yang sudah ditetapkan.

Untuk nilai $\mathrm{C}$ min dan $\mathrm{C}$ max agen kimia yang lain selain Besi $(\mathrm{Fe})$ masih sesuai dengan standart dan tidak melebihi baku mutu yang telah ditetapkan.

\section{Analisis dosis respon}

Setelah melakukan identifikasi bahaya selanjutnya melakukan analisis dosis respon yaitu mencari nilai RfD, dan/atau SF dari agen risiko yang menjadi kajian ARKL, serta memahami efek apa saja yang mungkin ditimbulkan oleh agen risiko tersebut pada tubuh manusia. Pada kajian ARKL air minum di Kabupaten Pasuruan diketahui bahwa agen kimia Nitrat $\left(\mathrm{NO}_{3}\right)$, Nitrit $\left(\mathrm{NO}_{2}\right)$, Seng $(\mathrm{Zn})$, 
Mangan (Mn) dan Besi (Fe) dapat masuk ke dalam tubuh manusia melalui jalur ingesti dan bersifat non karsinogenik . Sehingga nilai yang digunakan sebagai dosis referensi untuk ingesti yaitu RfD.

Tiap agen kimia memiliki dosis respon masing-masing. Hal ini berarti apabila nilai pengonsumsian lebih dari RfD akan menyebakan beberapa masalah kesehatan yang berkaitan dengan efek dari masing-masing agen kimia yang ada dalam parameter air minum untuk pekerja di Kabupaten Pasuruan Tahun 2017.

\section{Analisis pajanan}

Analisis pemajanan merupakan langkah untuk mengetahui jalur pajanan agen risiko ke dalam tubuh, apakah melalui inhalasi, ingesti, atau absorbsi agar jumlah asupan yang diterima oleh populasi berisiko dapat dihitung. Pajanan agen kimia dalam parameter air minum untuk pekerja di Kabupaten Pasuruan yang masuk ke dalam tubuh melalui jalur ingesti karena melewati sistem pencernaan. Bahan pencemar merupakan polutan non karsinogenik.

Perhitungan analisis pajanan ini akan menghasilkan nilai INK minimal dan maksimal untuk mencari nilai tingkat risiko kesehatan yang ditimbulkan akibat pencemaran agen kimia.

\section{Karakteristik risiko}

Karakteristik risiko kesehatan dinyakatan sebagai RQ (Risk Quotient) atau tingkat risiko untuk efek non karsinogenik. Nilai RQ menunjukkan tingkat risiko kesehatan akibat parameter pencemar (agen kimia).

Nilai RQ dihitung dengan membandingkan antara intake atau jumlah konsentrasi agen kimia yang masuk ke dalam tubuh manusia dengan berat badan tertentu setiap harinya dengan nilai RfD (Reference Dose) yang telah diperoleh berdasarkan literatur pada database Integrated Risk Information System (IRIS).

Berdasarkan Tabel 4 menunjukkan bahwa nila RQ minimal dan RQ maksimal tiap agen risiko adalah $<1$ yang artinya bahwa pada orang dewasa seperti pekerja di kelompok berisiko dengan estimasi berat badan $55 \mathrm{~kg}$, laju asupan pada orang dewasa 1 L/hari selama 250 hari/tahun untuk jangka waktu 25 tahun kedepan dikatakan aman apabila mengkonsumsi air minum di Kabupaten Pasuruan dengan nilai konsentrasi risk agent kimia air tidak lebih dari yang ada.

\section{SIMPULAN DAN SARAN}

\section{Simpulan}

1. Kualitas air minum untuk pekerja di Kabupaten Pasuruan menunjukkan sebagian besar parameter pencemar air minum memenuhi baku mutu sesuai dengan Peraturan Menteri Kesehatan Nomor 492 Tahun 2010 tentang Kualitas Air Minum

2. Agen kimia berisiko pada parameter air minum untuk pekerja di Kabupaten 
Pasuruan yang di konsumsi pada tahun 2017 berdasarkan hasil uji Laboratorium Kimia Fisika Media Air adalah Besi (Fe ), Mangan (Mn), Seng ( $\mathrm{Zn})$, Nitrat $\left(\mathrm{NO}_{3}\right)$, dan Nitrit $\left(\mathrm{NO}_{2}\right)$. Dari kelima parameter tersebut ada salah satu parameter yang melebihi baku mutu yaitu parameter Besi $(\mathrm{Fe})$.

3. Dosis respon agen kimia berisiko parameter air minum untuk pekerja di Kabupaten Pasuruan yang di konsumsi pada tahun 2017 dengan jalur pajanan melalui ingesti. Sehingga nilai RfD (dosis respon) yaitu Mangan (Mn) sebesar 1,4 E-1 $\mathrm{mg} / \mathrm{kg} /$ day, Seng (Zn) sebesar 0,3 $\mathrm{mg} / \mathrm{kg} / \mathrm{hari}$, Nitrat $\left(\mathrm{NO}_{3}\right)$ sebesar $1,6 \mathrm{E}+0$ $\mathrm{mg} / \mathrm{kg} /$ day, Nitrit $\left(\mathrm{NO}_{2}\right)$ sebesar 1E-1 $\mathrm{mg} / \mathrm{kg} /$ day dan Besi (Fe) 0,3 mg/kg/kg.

4. Nilai Intake agen kimia berisiko yaitu Mangan ( $\mathrm{Mn})$, Seng ( $\mathrm{Zn})$, Nitrat $\left(\mathrm{NO}_{3}\right)$, Nitrit $\left(\mathrm{NO}_{2}\right)$ dan Besi (Fe) pada air minum untuk pekerja di Kabupaten Pasuruan telah memenuhi Peraturan Pemerintah No 492 Tahun 2010 Tentang Persyaratan Kualitas Air Minum sehingga aman apabila dikonsumsi.

5. Hasil perhitungan karakteristik risiko parameter air minum di Kabupaten Pasuruan yang di konsumsi pada tahun 2017 menunjukkan nilai RQ dari keseluruhan sampel uji adalah $<1$. Artinya bahwa pajanan Mangan (Mn), Seng (Zn), Nitrat $\left(\mathrm{NO}_{3}\right)$, Nitrit $\left(\mathrm{NO}_{2}\right)$ dan Besi $(\mathrm{Fe})$ secara ingesti oleh pekerja yaitu orang dewasa dengan berat badan $55 \mathrm{~kg}$, tergolong aman untuk asupan harian sebesar 1L/hari dan frekuensi pajanan 250 hari/tahun hingga 25 tahun mendatang.

6. Manajemen risiko terkait air minum Kabupaten Pasuruan yang perlu dilakukan adalah upaya menjaga dan mempertahankan kualitas air minum yang dikonsumsi oleh para pekerja di Kabupaten Pasuruan serta melakukan pemeriksaan secara berkala dan melakukan pengendalian pada parameter zat pencemar yang melebihi baku mutu.

7. Komunikasi risiko terkait air minum Kabupaten Pasuruan dengan melibatkan pihak, DLH, Dinas Kesehatan dan Pemerintah daerah Kabupaten Pasuruan dalam bertanggung jawab terhadap kualitas air mulai dari sumber air minum sampai dikonsumsi oleh konsumen.

\section{Saran}

1. Pemerintah daerah Kabupaten Pasuruan sebaiknya bekerja sama dengan Dinas Lingkungan Hidup atau Dinas Kesehatan setempat untuk melakukan pemantauan secara terus menerus terhadap kualitas air minum di Kabupaten Pasuruan khususnya di tempat kerja dengan populasi pekerja yang cukup banyak.

2. Pemerintah daerah Kabupaten Pasuruan harus berusaha mempertahankan kualitas yang baik dari air minum yang ada di 
daerah dan lebih baik apabila kualitas air minum tersebut ditingkatkan.

3. Dinas Kesehatan di Kabupaten Pasuruan sebaiknya memberikan penyuluhan pada masyarakat Kabupaten Pasuruan khususnya para pekerja dan industri tempat kerja tentang air minum dengan kualitas yang baik dan pencemaran yang bisa mengontaminasi air minum serta bagaimana cara menjaga sumber air agar tidak tercemar dari bahan pencemar.

\section{REFERENSI}

1. Peraturan Menteri Kesehatan RI Nomor 173/MENKES/VII/1977 tentang

Pencemaran Air dari Badan Air untuk Berbagai Kegunaan yang Berhubungan dengan Kesehatan. 1977.

2. Peraturan Pemerintah RI Nomor 20 Tahun 1990 tentang Pengendalian Pencemaran Air. 1990.
3. Slamet, J.S. Kesehatan Lingkungan. Bandung: Gadjah Mada University Press. 2004.

4. Peraturan Menteri Kesehatan Nomor 492 Tahun 2010 tentang Persyaratan Kualitas Air Minum. 2010.

5. Mukono. Prinsip Dasar Kesehatan Lingkungan. Surabaya: Airlangga University Press. 2006.

6. Direktorat Jendral PP dan PL. Pedoman Analisis Kesehatan Lingkungan (ARKL). [e-book] Jakarta: Kementerian Kesehatan Republik Indonesia. 2014.

7. Said, N.I. Teknologi Pengelolaan Air Minum (Teori dan Pengalaman Praktis) : Jakarta Pusat. [Online] (www.kelair.bppt. go.id/Publikasi/BukuAirMinum/). 2008.

8. ATSDR. Toxicological Profile For Manganese. [Online] (https://www.atsdr. cdc.gov/toxprofiles/tp151.pdf). 2012.

9. Patty, S.I. Karakteristik Fosfat, Nitrat dan Oksigen Terlarut Di Perairan Pulau Gangga Dan Pulau Siladen, Sulawesi Utara. [Online] (http://ejournal.unsrat.ac .id/index.php/platax/article/download/7151 16661). 2014. 